Saudi Journal of Humanities and Social Sciences

Abbreviated Key Title: Saudi J Humanities Soc Sci

ISSN 2415-6256 (Print) | ISSN 2415-6248 (Online)

Scholars Middle East Publishers, Dubai, United Arab Emirates

Journal homepage: https://saudijournals.com/sjhss

Review Article

\title{
Realism in Trevor Rhone's Smile Orange
}

\author{
Dr. Sarah Terwase Shittu*, Pua Valentine
}

Department of English, Benue State University, Makurdi, Nigeria

DOI: $\underline{10.36348 / \text { sjhss.2020.v05i03.003 }}$ | Received: 30.01 .2020 |Accepted: 06.02 .2020 | Published: 21.03 .2020

*Corresponding author: Dr. Sarah Terwase Shittu

\section{Abstract}

The imaginative writer always aims at presenting a story to the audience (readers) that is not only interesting but appears to be true so as to keep them in love with his work. The literary creative writer skillfully mixes his imagination with the material obtained from the society to produce a piece that is a reflection of the realities of his environment. This paper therefore, examines Trevor Rhone's Smile Orange from a realist perspective. The paper reveals that the themes and literary techniques the author has adopted deepen our knowledge of the Caribbean Islands, particularly Jamaica whose socio-economic realities are sampled by the author. Through realism, as a literary theory, racism and sexuality among other thematic preoccupations and literary techniques like satire and the use of a creolised English, this paper appreciates Smile Orange as a piece that brings us face to face with the real experiences of the Caribbean. The history of the Caribbean has been captured in the paper to give the reader an insight into what the literature of the people may contain if it is realistic. The author is able to give us another dimension of the economic and social problems of Jamaica using the tourist industry as an example. By presenting those issues without making any revolutionary move makes the playwright a critical realist.

Keywords: Smile Orange, Caribbean Islands, racism, creolised English.

Copyright @ 2020: This is an open-access article distributed under the terms of the Creative Commons Attribution license which permits unrestricted use, distribution, and reproduction in any medium for non-commercial use (NonCommercial, or CC-BY-NC) provided the original author and source are credited.

\section{INTRODUCTION}

Smile Orange is a classical example of Caribbean literature. Caribbean literature is one variant of black diasporan literature that captures the experiences of the people of the Caribbean Islands which generally comprise of a conglomeration of people of different races and religious beliefs and with varying motives of being there [1]. The Caribbeans have a peculiar history that provides enough material for literary creative exercise. In the view of Julia Udofia, "Caribbean literatureis... a response by the individual writer to the historical realities of the area" (5). This implies that the fictional stories of Caribbean writers are reflections of the actual happenings in the Caribbean. This paper investigates how the realities of the Caribbean have been captured in Trevor Rhone's Smile Orange. Of course, the choice of Trevor Rhone for this paper was necessitated by the fact that some scholars of Caribbean literature tend to omit his name among the top Caribbean writers even though his contribution to this literature cannot be undermined. He paints a true picture of the Caribbean and his play takes a different toll in analyzing the economy of the Caribbean by looking at their tourist economy in the postcolonial period particularly in the seventies [2].
This suggests that there exist an ignorance of the contributions of Trevor Rhone to Caribbean literature, particularly the theatre even though he was one of the pioneer contributors to the Barn Theatre in his land [3].

\section{Brief History of the Caribbean}

The history of the Caribbean is peculiar. It does not evolve gradually and naturally out of a remote mythological and archaeological past, but begins abruptly with the "discovery" of the Bahamas in 1492 by Christopher Columbus. This abrupt beginning has led historians like Eric Williams and literary artists like V.S. Naipaul to assert that the Caribbean is merely a geographical expression which lacks a noteworthy history (Udofia 4).

This lack of creation refers to the dearth of monuments, libraries and other visible public amenities other than the remains of old plantation houses and memoirs of the slave experience. The European colonizers regarded the area as one whose economic potentials were to be fully exploited, but not a place to settle in permanently. This was why the plantation system was entrenched and thence, the proliferation of absentee landlords who enjoyed the fruits of their labour outside the West Indies. 
Initially, Columbus thought that the West Indies would open up a lucrative trade route for Spain. Also, because of the proliferation of gold body ornaments on the Bahamans he had met, Columbus concluded that there was an inexhaustible supply of gold to be obtained from the West Indies. Thus, his primary interest was the economic exploitation, and not the improvement of the area. Later on, it was discovered that the gold supply was finite and the colonizer's attention turned to the large-scale cultivation of sugar which was then a highly lucrative crop.

At all times, the European presence in the Caribbean was primarily motivated by selfish economic considerations. Because of this, they did not hesitate to undercut one another and eventually seek all inhumane means of obtaining a steady supply of easily replaceable labour for the effective cultivation of their plantations.

The West Indies can be referred to as an artificially created society because with the exception of the indigenous Indian population which was largely swiftly exterminated, the inhabitants of the Caribbean either migrated or were forcibly transported there. With this conglomeration of people of different races and religious beliefs and with different motives of being in the Caribbean, it was difficult to create a common Caribbean ethos, especially, given the fundamental inequalities created by the institution of slavery.

During Columbus's second trip to the Caribbean in 1493, he brought Spanish domestic cereals, vegetables, fruits and sugar cane to the West Indies. It is therefore; correct to regard the West Indians as an imported people in a largely imported environment. The early and later imperialists in the Caribbean had the sole motive of exploiting the natural, mineral and agricultural resources of the area both for personal benefits and for the good of their various mother countries.

The lure of gold, sugar and slaves thus precipitated imperialist forays into the area by Spain, Portugal, Britain, France and the Netherlands. Each of these imperialists fought to obtain a considerable share of the Caribbean wealth. And this gave rise naturally to piracy, double-crossing, brutality and lack of cohesion among the powers. Each group of Europeans had its own language, religion and political allegiances. They were also constantly engaged in the bid to protect or expand their territories and so had little opportunity or need to exert a unified political and cultural control over the non-European population.
Furthermore, the Europeans' inability to impose a common creolised cultural ethos on the slaves who were also multi-cultural in origin was exacerbated by the imperialists' lack of interest in the continuous spiritual and physical welfare of the Islands and its inhabitants. As a result, the negro slaves were largely left to evolve their own cultural expressions and value systems based on vestiges of different African traditions, various European influences and communal responses to the new milieu.

\section{Slavery in the Caribbean}

The Spaniards who were the original imperialists in the Caribbean already had a system of slavery which made it easy for them to resort to this method of procuring labour for their mines and plantations. Several sources of labour, including aboriginal Indians, white slaves and convicts labour were sought before blacks were brought into the West Indies. Negro slavery was initiated by the king of Spain on September 3, 1501 and began with the transportation of numbers of Christian negro slaves from Spain to the West Indies. African slave trade began shortly afterwards.

The mining of gold and to a greater extent, the discovery of the great economic potential of sugarcultivation in the world market precipitated the institutionalization of slavery in the West Indies. Plantation slavery began in the 16th century and from that time onwards, the fortunes of the Islands were greatly influenced by the price of sugar. Also, the requirements of the sugar industry determined the nature of the West Indian population. The cultivation of cane was highly capital-and-labour-intensive. The more sophisticated and efficient machines for extracting sugar were expensive and the crop itself was highly perishable which meant that it had to be processed shortly after harvesting. Also, the planting and harvesting of cane required considerable labour and the manufacturing process was arduous. The production of sugar on an economic scale therefore, required a considerable initial financial outlay and a large cheap labour force. Negro slavery provided easily available and replaceable unskilled labour. It also led to a change in the racial composition and social structure of the Islands.

Under slavery, the humanity of the blacks was progressively eroded, especially with the arduous work hours, stringent penalties for absenteeism and the promulgation of slave codes which gave legal sanction to slavery. These codes deprived the slaves of the freedom of movement and the simplest exercise of their freewill. For instance, they could not marry without their masters' permission, could not own property, were considered to be moveable property and could be punished even unto death by their masters. 
This brutally indifferent method of slavery, coupled with the racial and cultural diversity found in the West Indies and the uprootment and dispossession experienced by the African slaves helped to rob the Negroes of a sense of historical continuity and emphasised the lack of control over their lives. It also gave rise to such psychological traumas as alienation, rootlessness, inferiority complex and the creation of the colonial mentality. The cultivation of cane was thus, the basic reason for the institution of slavery and had important influences on the Caribbean psyche, such as the engendering of the isolationist outlook and an endemic and crippling sense of provincialism, all of which are difficult to eradicate from the 21 st century Caribbean mentality.

\begin{abstract}
Abolition
There were three basic reasons for the abolition of slavery: economic, political and humanitarian. By the 19th century, the cultivation of sugar in the British and French West Indian colonies was no longer economically viable because cheaper sugar was obtainable from India and Brazil. Sugar producers in the colonies discovered that they produced sugar at a greater cost than its selling price, thus making it difficult for the plantation owners to make profit after caring for the needs of the slaves.
\end{abstract}

Politically, the abolitionist move was part of the increasing global moves by the industrial bourgeoisie against the landed aristocracy, such as the French revolution of 1789 and the victory of the North over the South in the American civil war.

On humanitarian grounds, slavery was considered the height of man's inhumanity to man and so, such figures as William Wilberforce sought the legal end to the institution of slavery. Abolition Acts were passed in Denmark in 1803, Great Britain in 1807, France in 1817 and Holland in 1818, while slavery was legally abolished in the British colonies in 1833, French colonies in 1848, and Dutch colonies in 1863.

There is, in Caribbean literature, the predominance of the alienation theme in various forms: homelessness, rootlessness and exile. It is a situation of being a part of what you could not become. So, the primary cultural commitment of Caribbean writers remains the search for identity and self-discovery. The fragmented nature of the society gives the West Indian an acute sense of exile and because the literature of this area reflects and attempts to come to terms with the consequences of colonization. This is what Edward Baugh describes as "colonial literature"(13). Caribbean literature then, establishes the West Indian identity as different from the European, and neither is it African, Chinese nor Indian but a strange and pleasurable mixture of all these. The playwright in the New World then, is engaged in an attempt at articulating a trueness of being.
Literature of the Caribbean discusses racism, loss of identity, sexuality, escapism, among other issues salient to its society. Some writers of the Caribbean origin are Derek Walcott, V.S. Naipaul, Samuel Selvon. Giving account of V.S. Naipaul's creative writing, Udofia says in the works of Naipaul, we find characters "who are either failures because of their inability to express and realize their full potentials or characters who are mediocre but who nevertheless are precipitated into success by the mediocrity and form less ness of the society"(5). One of his works is Miguel Street which is a collection of his short stories. Derek Walcott, on his part as a Caribbean writer, believes that the West Indian must move towards refashioning the present. He posits in his works that the West Indian must overcome the sense of inferiority and lack of cohesion which is the heritage of dispossession and alienation (Udofia 5).

Indeed, the plot of Smile Orange reflects the urgent need for Jamaica to resist economic domination of western superpowers. Interactions between workers and tourists in Smile Orange expose the plight of black Jamaicans seeking economic advancement in spite of the imbalance of power emblematic of the tourist economy of a formerly colonised nation.

Anti-colonialism's language of freedom has become uncomfortably mimicked by neoliberal celebrations of the free-market as the height of selfsufficiency, throwing this oppositional project into crisis. The 1970s, poised between the end of a system of international domination centered on nation-states and the rise of another based in global institutions like the World Bank and IMF, mark the moment in which the disjunction between nationalistic anticolonial discourse and postcoloniality begins to emerge.

By figuring their engagement with postcolonialitythrough drama, Smile Orange highlights performance as a response to this new context. Performance has generally been theorized as anathema to true resistance in a colonial setting, but examining how it functions in the play sheds light on postcolonial as opposed to anticolonial attitudes towards the strategy.

\section{Theoretical Framework}

Realism has been selected to serve as the theoretical basis for this paper. This theory was first applied to literature in 1850 but continues to be relevant in literary criticized because " All writers of whatever persuasion, thrillers, romances, autobiographical political or sociological, have always had a fondness for what canpass as the truth so as to carry their readers along or maintain them". (Asoo, Ferdinand 17). Realism as literary theory demand that actions and characters in a work of art should be a true reflection of real life experiences or happenings. In the opinion of G.H Lewes, the relevance of realism to literary criticism is incomparable because "Art always aims the 
representation of Reality... of truth and no departure from is permissible..." (cited in Asoo 18). Therefore, this study analyses Smile Orange to point out realistic elements in the play. As observed by Ferdinand Asoo, Realism can be looked at in two perspectives. The kinds of realism are socialist realism and critical realism. In socialist realism, the writer presents the social facts in his society through fiction and makes attempt of revolution as solution to the ugly realities. In critical realism, the artist also brings the realities of the society to the people but does not make any revolutionary attempt. He rather allows the readers to think and decide on their own on what they will do. This is the kind of realism that serves well for Smile Orange because even though Rhone has unveiled the social ills in the Caribbean, he does not make any revolutionary move in the work.

\section{Themes}

Many themes can be deduced from this play but in this paper, racism, escapism and sexuality have been discussed as the major themes in the novel.

\section{Racism}

Racism is a social situation where people are treated, looked upon, or addressed in a certain way whether politically, economically, or sociallydue to the colour of their skin. Where this problem exists, human beings are either unduly favoured at the expense of others or are sheerly discriminated against in all important issues because of their race. Caribbean literature, portraysa high level of racial discrimination and segregation between the blacks and the whites. People who are of the white race first of all see themselves as superior and thus behave in that manner, and enjoy more rights as human beings than the black people. In "Smile Orange" by Rhone, racism is exhibited in the economic aspect of life most than in any other aspect of life. Among the black characters in the play are Ringo - a waiter at Mocho Beach Hotel, Cyril - a busboy at Mocho Beach Hotel, Miss Brandon, among others. A 'coloured' (with mixed colour) character in the play occupies a position that is higher than the rest of the characters mentioned. More so, he is married to a white woman. This suggests that the society in which the play is set is thickly imbued with racism. Major White character in the play is The Assistant Manager - of the hotel. On a general note, all the black staff of the hotel occupies positions that are inferior and which make them more or less servants to the white. Miss Brandon is the only person whose kind of job is not bad but is however nothing commendable ascompared to the post of Assistant Manager held by coloured man. More so, the wages of the black staff are so poor that they tend to indulge in fishy deals to cope with life. The act of giving sexual satisfaction to some white ladies and seducing them to give you financial aids is a deal that Ringois engaged in. Cyril is also initiated into the act (Act Two, 118-123). This is the same situation with Miss Brandon. Through her phone chats with her friend, we get to know that she isinto commercial sexual life. She says: "I want to go to America and it don't matter; (Hiss) Di bed business? Di man have di money and I want to go..." (127). These behaviours of the characters and their exploitative attitudes to the white foreign tourists are indeed condemnable but the economic realities surrounding them have made no alternative than these available. One cannot therefore condemn their behaviours first without first of all condemning their issues that have led them into that.

\section{Escapism}

Escapism is a theme that features in many Caribbean texts. Often times than not, we find characters trying to dodge away from the realities surrounding them such as poverty, racism, family responsibilities and so on, in the face of their economic challenges. Apart from the text under review, Miguel Street by V.S. Naipaul has this.

In Smile Orange, we come across a character known as Ringo who is trying to escape from his family responsibilities. He leaves home without giving his wife some money for feeding at homeand the woman traces him to his place of work, the hotel. Upon seeing his wife, Ringo begs Joe, his colleague and friend, to hide him in the refuse bin so that his wife would not find him. When he is finally in the bin he says: "Remember what I told you, you don't see me. A gone to port Antonio". Joe also does the best he can for his friend by deceiving the Assistant Manager by misrepresenting the identity of Ringo's wife to him as a mad woman who could be sent away with some dollars. The scene of the drowning of people in the port in the play is also because Ringo wants to escape the problem of his wife's brothers disturbing him to find them job that he recommends them to be life guards in pool even though they don't know how to swim. Miss Brandon, the Telephone Operator, is also willing to offer anything for what can let her go to America because she sees America as a better place of living. This is no doubt also an escapist attitude.

These efforts by the characters in the different works to escape surrounding situations in their environments is indeed an act of reality as this paper has stated above that the fragmented nature of the society gives the West Indian an acute sense of exile - a belief that until they flee from those situations it can never be better with them.

\section{Sexuality}

Sexuality is the state of being occupied with sex. Inmost instances, the kind of sex found here is that of commercial sex where people offer sex services to others in order to receive gains from them. This use of sex for commercial purpose is also dominant in this play. The realities of the society have compared the citizens to seek every means of survival, one of which 
is sexual service. There are limited job opportunities for the blacks in Smile Orange and even the few ones available give meager wages that cannot cater for their colossal need. Also, this sex is common among the characters. In Act Two, we come across Ringo who has been into the game of giving sexual satisfaction to some white ladies and getting favours from them and initiating Cyril (Busboy) into the game (120-121). Miss Brandon also goes out with the one-foot white man to get money from him after they must have had sex. She says: “... one thing I tell you, I not giving away my pearl for nutten. Is all I have. It have to work for me."(143). This means that she is ready to render sexual service to get her interest.

\section{Poverty}

The land and people of the Carribean are highly esploited and made poverty striken. Due to their race, the black people of the Carribean Island neither have access to education nor good jobs thence are overtly destitute. Back in the days, when broad-day slavery was still practised, the Carribeans worked on the plantations while the white masters (foreigners) enjoyed the fruits of their labour. Trevor Rhone captures the present day Carribean in his Smile Orange by revealing to us the economic challenges of black people in that society through the experiencesof the black characters in the play. The waiters at Mocho Beach Hotel are blacks and each of them earns below their immediate needs like food. Ringo's inability to provide food at his house before living for work and the scenario ensuing from that is a point too bodacious to wave aside in this regard.Ringo's destitute life has led him to do several things, some of which he expresses dislike for openly thus "Di things a man have to go through to make a dollar, sometimes you have shame of yuhself'. (105). The economic condition of other characters like Joe, Cyril and Miss Brandon who are also workers at the hotel are in no way better than Ringo's. Therefore, the black charactesr in Smile Orange are really generally poor.

\section{Style}

It has already been established by this work that the Caribbean society was characterised by a hybrid culture and the linguistic implication of this situation is a creolisedEnglish. Terevor Rhone uses a creolized kind of English in this play that further supports our proposition that the play can be studied as a realist one. Right at the beginning of the play, we get this kind of English in the conversation between Miss Brandon and her friend. "[....] Di Assistant Manager boy jus' killing up himself. One piece of chaos! Guess wha' dem call him up here? Flap flap". (94). She also tells her friend, "Yes, him nuh want di pearl for nutten". (95).Pearl is used here as a euphemism of the clitoris and symbolic of the lady's precious body. This is the kind of English used by Joe, Ringo and Cyril throughout the play. Other expressions in the play increolised English are "me see dem. Dem nervous, though" by Joe (240), "it all right, sar" by Busboy (142), and so on. The difference between this and standard English is too clear to doubt the point made here but for more clarity some lexicons in the language are isolated thus:

\section{Nutten -Meaning nothing \\ Sar - meaning sir \\ Dem - meaning them}

This manner of the use of language by the author is purposeful and effective. The author's use of language here connotes social class and race; standard English is associated with higher, creole with lower, social status.

\section{Satire}

Realist texts often employ satire as a tool of depicting the social problems of the society in order to give rise to positive change that will bring about positive development. Smile Orange is a play that is satirical in nature. The play has hilarious scenes and funny characters whose action emits laughter from the audience. One funny episode in the play is when Ringo is coaching Busboy on how to engage a white lady who is a guest in the hotel to know if they need a Jamaican guy. The demonstrations by Ringo to show how his trainee could carry out the act and the former's impatience over the latter's slow learning speed creates a laughable scenario to the audience. In this excerpt, Ringo act as a guest so Bushboy make some advance to him thus:

\author{
Busboy: dinner \\ Ringo: yes, I enjoyed it very much \\ Rusboy: can I take you out to a night club \\ tonight, Ma'am (touching Ringo) \\ Ringo: you skid! You skid! You can't touch di \\ woman! ..... (122)
}

By exposing Busboy'snaiveenessand Ringo's expertise in what he calls "playing a part" (120), the playwright succeeds in creating a lot of fun. Moreso, Busboy's lisp which makes him to pronounce 'sh' as 'ch' thus says 'choping' instead of 'shoping'is caricatured by Ringo. Indded, it is quite funny. These humorous scenes among others in the play are satiric because the playwright uses them to expose the indecent life that prevailedthe Jamaican societyin the 1970 s and 1980s, through the tourist industry which is just a glimpse view of the economy of that Island.

\section{CONCLUSION}

There is always the important need to expose the realities of the society that lead to its decadence. The need for the writerto embrace this task more seriously than any other person especially in societies that their histories have given them a mark of retrogression that age or time has not yet been able to erase cannot be over-emphasised. Therefore, treating Trevor Rhone's Smile Orange as a realist play is not 
out. This paper has treated the racism, sexuality, escapism, and poverty as major concerns in it. The realities of the Carribean which focuses on the tourist industry is indeed peculiar, interesting and worthy of a critical attention like this.

\section{REFERENCES}

1. Baugh, E. (Ed.) (1978). Introduction. In critics on Caribbean literature (pp.1-9). London: George Allen and Unwin.

2. Dalleo, R. (2011). Performing Postcoloniality in the Jamaican Seventies: The Harder They Come and Smile Orange. Postcolonial Text, 6(1).

3. Rhone, T. D. (1981). Trevor Old Story Time and Smile Orange. New York. Longman. 